\title{
Religiosity and Resource Allocation in Marajó, Brazil
}

\author{
Emma Cohen ${ }^{\mathrm{a}, \mathrm{b} *}$ \\ Adam Baimel $^{\mathrm{c}}$ \\ Benjamin Grant Purzycki ${ }^{\mathrm{d}}$ \\ ${ }^{a}$ Institute of Cognitive and Evolutionary Anthropology \\ University of Oxford \\ 64 Banbury Road \\ Oxford, UK OX2 6PN \\ ${ }^{\mathrm{b}}$ Wadham College \\ Parks Road \\ Oxford, UK OX1 3PN \\ * contact author email: emma.cohen@anthro.ox.ac.uk \\ ${ }^{\mathrm{c}}$ Department of Psychology \\ The University of British Columbia \\ 2136 West Mall \\ Vancouver, BC V6T 1Z4 \\ Canada \\ ${ }^{\mathrm{d}}$ Department of Human Behavior, Ecology and Culture \\ Max Planck Institute for Evolutionary Anthropology \\ Deutscher Platz 6 \\ 04103 Leipzig, Germany
}

\begin{abstract}
Current research suggests that certain features of religion can harness our sociality in important ways, curbing selfish behavior and/or boosting prosocial behavior. If this is the case, embodied symbols of religious devotion should induce these effects. To test the claim that religious symbolism has an effect on sociality, we conducted the Random Allocation Game with a symbolic prime in Pesqueiro, on the Island of Marajó, Brazil, among Christians. Our prime - a Bible and a crucifix pendant - appears to have influenced the allocations made toward distant coreligionists; people who played the game in the prime condition allocated more coins to the distant coreligionist. Additionally, self-reported beliefs about God's knowledge and punishment had strong effects on fair gameplay across games.
\end{abstract}

Keywords: religion, priming, prosociality, supernatural punishment, Brazil

Acknowledgements: Cohen collected data and contributed to writing the introduction, field site description, study description, results and the discussion in this manuscript. She was supported by a British Academy Fellowship during its preparation. Baimel and Purzycki ran analyses and contributed to writing the introduction, study description, results, and discussion. Purzycki was supported by CERC during the preparation of this manuscript. We thank Andrezza Barbosa, Cris Penante, and Roberto Junior for help collecting data and to the people of Pesqueiro for their 
participation and assistance. Many thanks to Joe Henrich, Ara Norenzayan, and Aiyana Willard for their helpful comments on earlier drafts of this manuscript, to Rita McNamara for her assistance with code, and to Wesley Wildman, Joseph Bulbulia, and the anonymous reviewers for their feedback. Special thanks to Coren Apicella.

\section{Introduction}

Growing evidence indicates the influences of agency detection and religious supernatural agency on human cooperation. Current research examining the social effects of agency with the use of psychological primes suggests that indices of agency — whether supernatural or otherwise - can curb antisocial behavior or boost prosocial behavior (cf. Galen, 2012). The perception of being watched induces norm adherence and minimizes the temptation to break rules (Haley and Fessler, 2005; Nettle, et al., 2013). Additionally, threat of punishment may also minimize defection in cooperative ventures (Mathew and Boyd, 2011). Observant and punitive agents can contribute to the persistence of cooperation and norm adherence but monitoring and punishing others' social behavior is a costly endeavor. Johnson (2016) has argued that supernatural agents can offset these costs. As gods are psychologically salient concepts, such deities may trigger and stabilize the motivational forces behind cooperation. Indeed, the religious priming literature shows a fairly robust effect for religion's social effects (Bering, McLeod, and Shackelford, 2005; McKay, et al., 2011; Randolph-Seng and Nielsen, 2007; Piazza, Bering, and Ingram, 2011; Pichon, Boccato, and Saroglou 2007; Shariff and Norenzayan, 2007; Shariff, et al., 2016).

Norenzayan and others (Norenzayan, 2013; Norenzayan, et al., 2016; Purzycki, et al., this volume) extend this hypothesis and posit that endorsing beliefs in relatively more knowledgeable, punitive, and moralistic gods widens and stabilizes cooperative networks beyond local communities. If psychological primes can harness the alleged effects of religion in experiments, and if beliefs in moralizing, punitive gods who know people's thoughts and behaviors function to widen the scope of human cooperative behaviour, then religious symbols of those gods should enhance cooperation toward others in one's local community and also extend it toward those outside of one's local community.

To date, most studies have been conducted among a) North American and b) predominantly university student samples with c) an emphasis on the moralistic, Abrahamic religious traditions. Such a focus constrains interpretations concerning the generalizability of hypothesized effects (see Henrich, Heine, and Norenzayan, 2010; Sears, 1986). Many traditions around the world place a relatively higher emphasis on hagiolatry (i.e., saint-worship), where the spirits of sanctified humans have a strong connection to a central deity, as in the case of Catholicism. If punitive and all-knowing deities have strong connections to other spirits that elicit devotional practices, do the latter contribute to sociality in similar ways as the former, expanding the moral circle to include distant strangers? Or, in situations of conflicts of interest between individuals, are local spirits and saints rather perceived as patrons who support the local, individual interests of their "client" devotees rather than those of the unknown individuals of a distant community?

We examined these questions in the community of Pesqueiro, Marajó Island, Brazil. This is the only Christian, and predominantly Catholic, sample in the present volume with a virtual absence of competing traditions living alongside target samples (see Atkinson and McNamara \& Henrich, this volume for other Christian samples). Christianity also has centuries-deeper historical roots in Brazil than the other Christian samples and is integral to Brazilian culture and 
society. As such, the predicted effects of psychological primes and the aforementioned components of religion ought to have clearer effects than the other Christian traditions examined in the present volume. Below, we provide a brief overview of the region, site, population, religious history, and context before describing the experiment's implementation and results. We conclude with a brief discussion of findings and implications for the current approaches to understanding the social effects of religion.

\section{Field Site}

The archipelago of Marajó occupies an area of approx. $50,000 \mathrm{~km}^{2}$ at the mouth of the Amazon, in the northern Brazilian state of Pará. The easternmost island in the archipelago, the Island of Marajó, is the largest fluvial-marine island in the world (Schaan, 2008). The island vegetation is split between the terra firme, floodplain and flooded forests of the west and the savannah and mangroves to the east, where the present study was based. The year is also split between rainy and dry seasons (January-June and July-December, respectively), which define and transform the landscape via a vast drainage system of rivers, bays, lakes and streams. Buffalo and cattle ranching as well as timber and palm extraction drive the economy. Fishing is also an important economic activity throughout the archipelago and across the eastern savannahs, where fish remain trapped in seasonal lakes after floodwaters of the rainy season recede. Large earthen mounds discovered by archaeologists at the beginning of the 20th century have been the focus of intense debate concerning the complexity of pre-Columbian society in the area and the broader Amazon region. Recent research suggests that the mounds indicate the presence of complex social structure, including hierarchical chiefdoms, previously thought unsustainable within this "counterfeit paradise" (see Heckenberger, et. al., 2007; Schaan, 2008).

The island is famous for its large numbers of buffalo, a rich source of meat, cheese, and milk, and also a common form of transport. Marajó also lies at the heart of Brazil's boom in açaí palm production, represented by two main industries, heart of palm and açaí fruit. The fruit's popularity has grown regionally as a staple food and is now instantly recognizable nationally and internationally as "superfruit" and fashion food (Brondízio, 2008). Socioeconomically, however, the region's infrastructure, public services and facilities are underdeveloped and it remains isolated from the progressive urban centers of the mainland (GPTDA Report, 2012).

\subsection{Economy}

The small fishing village of Pesqueiro, where the present research was conducted, is situated on the east side of Marajó Island. Pesqueiro falls under the jurisdiction of Soure, one of seven municipalities within the island's Ararí micro-region. The village is located within the first marine reserve of the state of Pará, a designation that has served to protect thousands of hectares of mangrove since 1989. According to records we obtained from the local health authority in 2013, ninety-two families (309 individuals) were registered as living in the village. Soure is the nearest main town (approx. $8 \mathrm{~km}$ ) and is accessible via an asphalted road. According to the 2010 census of the Brazilian Institute for Geography and Statistics (IBGE), the municipal population of Soure was 23,001 (including both the town inhabitants and all rural populations in its 3,517 $\mathrm{km}^{2}$ territory). Access from the mainland to the nearest main port, Cametá, is via a 3-hour boat journey across the Bay of Marajó from the state's capital, Belém.

Pesqueiro mainly lives off the revenue of fishing and tourism. Dwellings are predominantly small, multi-room single-storey wooden structures, raised on stilts to protect from 
the flooding that occurs during the heavy rains. The entrance to the village turns off the main road just before the road ends and merges with the sands of Pesqueiro beach. The main street of unpaved rust-red clay and sand runs parallel to the beach, before it curves around past the shop and bar, primary school, gymnasium, and church to the expanse of white sand that recedes to the Bay of Marajó. Fish are sold in the town of Soure and in bars and restaurants on Pesqueiro beach. Some of our research participants made a living by doubling their sources of income. For example, one woman supplemented her main income as a domestic cleaner with bar work on the weekend.

The town of Soure has 12 pre-schools, 22 primary schools, and 3 middle schools. The Federal University of Pará also has a presence in the town, offering courses in higher education. In Pesqueiro and other rural communities outside of the main town, there is typically just one primary school providing basic education. On completing this level (at approximately 12 years of age), students finish their elementary education in Soure, where they also continue to middle school. Overall, our sample's average number of years of formal education was 8.67 (SD = 5.09 with 9 missing values), which approximately corresponds to a complete basic education (i.e., age 6-13.) School children travel between Pesqueiro and Soure on a scheduled school bus service provided by the town council.

There is one health station in Pesqueiro where the community doctor attends patients on specific days. There is no regular public transport to and from Soure. Access to a bicycle or private vehicle is required to travel to the town, where people may buy groceries or sell their produce. Tourists and others interested in visiting the mangroves and the beach may hire a taxi (car or motorcycle) in Soure. The majority of visitors to the area are local weekend day-trippers, who enjoy a leisurely lunch on the beach and return to their homes, relatives' homes or guesthouse accommodation in Soure in the evening.

In recent years, the state government has invested in community-based programmes to raise awareness of environmental issues and promote tourism. The aim is to develop "community-based tourism", in which local individuals receive and offer hospitality to visitors to the area. These investments have brought some important communications developments, such as mobile phone signal and internet.

Locals refer to the village and its people as "the community" (a comunidade). People talk and gossip at ease in the small convenience store and at the football ground a couple of hundred metres away. The convenience store doubles as a bar and meeting venue where men get together at the weekend to play pool and chat over a beer. Women meet and chat casually when they stop by for basic groceries. ${ }^{1}$ The community holds regular "Luais", or beach gatherings, where locals play live or recorded music and rhythms, such as carimbó and technobrega, and enjoy some food and drink together. These parties bring people from towns and villages across the region. If nightlife is a quiet in Pesqueiro, Soure offers options for those who can afford them.

\subsection{Religious Background}

Spanish and Portuguese colonizers introduced Catholic Christianity to Brazil in a mercantile mission of slavery and salvation in the early 16th century (see Ribeiro, 2000). The commercial interests of the secular mission were validated through a divine mandate to convert indigenous

\footnotetext{
${ }^{1}$ Indeed, it was at this bar that we overheard commentaries about the study: "They left him alone there in the room. He'd have taken the coins if he wanted to!" This met with: "If he' $d$ taken all the coins, everyone in the village would know he was a thief!"
} 
people and African slaves to Roman Catholicism. This mandate was carried out mainly by Jesuits, Franciscans and Carmelite missionaries, whose utopian struggle for the universal spread of Christianity eventually clashed with the inhumane activities of the colonial government, leading to tensions and internal conflicts. Many missionaries were ultimately expelled from the new empire. By the end of the eighteenth century, the colonialist mission had all but exterminated the indigenous population.

The city of Belém, at the mouth of the Amazon, was founded by the Portuguese in 1616 (Alves Filho, de Souza Jr \& Neto, 2001). After several failed military attempts by the colonizing forces to dominate the indigenous population of Marajó, Jesuit priests finally succeeded in establishing a settlement on the island in 1658 and a peace treaty with the Portuguese. By 1680 , the first farm estate (fazenda) was founded, launching the region's influence as an agricultural centre and national provider of cowhide (da Cruz, 1987). Soure's foundation dates to this period, the early 18th century, when it was a parish by the name of "Menino Deus" (lit. "Boy God").

Catholicism has been the predominant religion in Brazil ever since these early days of imperial expansion. The Portuguese colonizers forbade other forms of religious devotion derived from indigenous and African slave cultures, though these have survived through syncretic mixing and revival (Cohen, 2007; Johnson, 2002). Brazil remains the largest Catholic country in the world, but the landscape of religious affiliation is changing rapidly. Government census data recorded a drop in the percentage of Catholics from 95\% in 1940 to 65\% in 2010 (IBGE). During the same period, Protestantism increased by $19 \%$ (from $3 \%$ to $22 \%$ ). The rise of Protestantism is marked by three key points in its history; the introduction of Pentecostalism from Europe in the 1910s, a second-generation expansion promoted by the arrival of American Pentecostal missionaries in São Paulo in the 1950s, and a third wave of neo-Pentecostalism in most recent decades, characterized by health-and-wealth prosperity theology. Among urban youth, the number of Evangelical Protestants has now begun to surpass the number of Catholics and, if trends continue, demographers project a Catholic minority in Brazil within the next three decades (Coutinho \& Golgher, 2014).

Rural northern Brazil, while no exception to the changing trends in religious affiliation, remains predominantly Catholic. According to the latest census figures (IBGE, 2010), the state of Pará was 64\% Catholic and 27\% Evangelical Protestant; Soure was 79\% Catholic and 17\% Evangelical Protestant. In Soure, of the 458 who declared having no religious affiliation, approximately half were women (221); only 9 declared atheism. This contrasts with national figures, which register a greater number of men in the growing number of Brazilians who selfdeclare as having no religious affiliation.

\subsection{Current Beliefs and Practices}

The vast majority of Brazil's Catholics engage with formal religion and the church only on special occasions (e.g., weddings, funerals, etc.). In Pesqueiro, a well-maintained church, Igreja Santa Luzia, with a brightly tiled entrance and facade, is located at the heart of the community. Regular masses, services, prayers and other social activities are organized and attended mainly by women and the elderly. A fenced concrete basketball court just across the street and the beach beyond it offer diverting distractions to the children. The evangelical protestant minority of the village attend church in the main town of Soure.

The highlight of the village events calendar is the local realization of the state-wide religious procession and festival known as the Círio (Alves, 2005; Pantoja \& Maués, 2012). Held annually in December, the focal procession involves the whole community in a celebration 
dedicated to the patron saint, Santa Luzia and, by extension the patron saint of the state, Our Lady of Nazareth. The event imitates elements of the region's central and traditional Círio in the state capital of Belém, in which an image of the Virgin Mary, Our Lady of Nazareth (Nossa Senhora de Nazaré), is processed through the city street to the Basilica Cathedral, accompanied by 2 million devotees and visitors. In Pesqueiro, the saint is carried from a farm outside the town to the village church, and people join on foot, bicycle, horse and buffalo. Houses and overhead cables are festooned with bunting, flowers and ribbons, and the wooden arch that straddles the street at the centre of the village is freshly repainted with imagery and sentiments dedicated to Santa Luzia. As Our Lady of Nazareth is the focus of the region-wide Círio festival and the patron saint of the state and region, we used her as another deity, alongside God, for targeted questions and subsequent effects tests.

\section{Study}

In this section, we briefly discuss the experimental set-up and conditions of the study followed by a description of our sampling strategy. We then detail the demographics of our sample with particular attention to responses to our religiosity questions including a systematic comparison between how participants thought about God and Our Lady. We then present and discuss our experimental results.

\subsection{Methods}

All original protocols in English can be obtained here: http://hecc.arts.sites.olt.ubc.ca/files/2016/04/CERC-Project-2013.zip. Translated materials are included in the online supplementary materials. Given the bulk of these materials, we refer readers to these materials for the full data collection procedure.

\subsubsection{Experimental Games, Prime, and Materials}

To measure the expansion of sociality, we used the Random Allocation Game (Hruschka, et al. 2014; Jiang 2013; McNamara, Norenzayan, and Henrich, 2016). Participants played two counterbalanced core games: 1) the Local Co-Religionist Game (a local co-religionist vs. a geographically distant co-religionist, and 2) the Self Game (another distant co-religionist vs. the participant). Roughly half of the sample was randomly assigned to the prime condition and the other half to the control condition. For each game, participants were instructed to think of which cup they would like deposit a coin, and then to roll a fair, two-colored die to determine where the coin would go (if black, then the coin would go into the coin people thought of, if white the coin was supposed to go into the opposite cup). If players played by the rules, coins should be randomly allocated between the two cups. If people systematically bias allocations, however, then coins should deviate from a random, binomial distribution (see Purzycki, et al., 2016; this volume for further details). Each coin was worth 50 Brazilian cents ( $\sim 0.15$ US).

The prime consisted of an open Holy Bible (Bíblia Sagrada) overlaid with a cordnecklace with a wooden cross pendant, two indicators relating to God. The items were placed on the corner of the table on which the games were played, approximately half a meter from the seated participant and sufficiently distant that the print could not be read from the participant's game-playing position. Items were selected on account of their readily recognizable religious importance and relevance to both Catholic and Protestant participants. In the control condition, 
participants played the games in the absence of any additional items. Our local research assistant was able to identify religious affiliation in advance of the experiment session and coded each individual for whether they were Catholic or Evangelical Protestant (our CATHOLIC variable). If participants were Catholic $(n=60)$, the distant coreligionist (DISTANT) was a Catholic from Rondon; if participants were Evangelical $(n=17)$, the DISTANT was an Evangelical from Rondon. Rondon is a town in the mainland interior of the state of Pará that would have been familiar to participants by name alone, but not likely to have close acquaintances. Likewise, cups for local co-religionists (LOCAL) conformed to participants' affiliation.

\subsubsection{Control Variables}

In addition to standard demographic variables including sex, age, years of formal education, and number of children, we asked a wide range of questions pertaining to religion and intergroup relations. Among our target religiosity variables were: affiliation (Catholic or Evangelical) and questions pertaining to spiritual agents' punishment, knowledge, rewards, and moral concern. Questions concerned both God and Our Lady of Nazareth.

The punishment index was the mean of responses to two binary questions: 1) Does God/Our Lady of Nazareth ever punish people for their behavior? and 2) Can God/Our Lady of Nazareth influence what happens to people after they die? We measured deities' knowledge of participants' affairs using the mean of two other dichotomous questions: 1) Can God/Our Lady of Nazareth see into people's hearts or know their thoughts and feelings? and 2) Can God/Our Lady of Nazareth see what people are doing if they are far away in New York? We measured participants' perceptions of how rewarding these deities are by asking them How often does God/Our Lady of Nazareth assist people in their lives or reward them for proper behavior? Responses to these questions were on a 5-point scale: (4) Every day or multiple times per day; (3) A few times per week; (2) A few times per month; (1) A few times per year; and 0) Very rarely/never.

We wanted to ensure that we controlled for intergroup relations in the event that participants' views of co-religionists varied. Using a visual Fusion scale (Swann, et al., 2009), we asked how emotionally close participants felt towards co-religionists from Rondon and coreligionists from Marajo. We also asked players to rate how religiously similar their own religious community was with that of their co-religionists in Rondon. This was on another visual scale from -2 (very different) to 2 (very similar).

As previous research (Hruschka, et al., 2014; McNamara, Norenzayan, \& Henrich, 2016) found that the more effective local secular forms of justice positive correlate with fairer gameplay, we asked participants to rate how good they thought the police were on a scale from 2 (very bad), to -1 (bad), 0 (neither good nor bad), 1 (good), and 2 (very good). See Purzycki, et al., 2016; this volume for further methodological details.

\subsubsection{Ethics Approval}

This project was approved through the University of Oxford's ethical review board (SAME/CUREC 1A 13-50). 


\title{
3.2. Sampling, Locations, and Execution
}

All experiments were conducted on a single day with follow-up interviews conducted over the course of the subsequent week. A random sample of participants was selected from a complete register of all adults in the town. Individuals were approached in their homes and invited to take part in the study. The invitation provided the following information and was delivered by Cohen and a local research assistant:

\begin{abstract}
You have been randomly selected to participate in a research event that is being organized by an international team of social scientists. The research will look at how people make decisions and will involve answering some questions (there are no right or wrong answers) and taking part in some decision-making activities. It will take place on Saturday at the school. You will receive financial compensation for your time - 10 reals for showing up and more for participation. Participation is entirely voluntary and you can leave at any time if you want.
\end{abstract}

Participants were asked if they would like to take part and, if so, to indicate their preference to attend the morning, afternoon or evening session. On the whole, participants who were available on the scheduled day agreed to take part; if unavailable, participants were invited from a reserve list (also randomly selected, and in random order). A total of 128 individuals were invited, of whom 34 were unavailable. Fourteen people did not show for their agreed session, leaving a final total of 80 participants split evenly across the three sessions (morning, afternoon, and evening).

On arrival at the experiment venue, each participant received a numbered ticket indicating order of arrival. Once all participants for the session had arrived, the study was introduced and informed consent was obtained. A local research assistant provided the standard information to the group orally, including instructions to refrain from speaking about the study activities to anyone. All participants agreed to sign the consent form. Research assistants then led participants individually and in order of arrival to the experimental rooms, where they explained the game instructions. Following a comprehension check, research assistants left the rooms and participants performed the games alone. There were two rooms, one with religious primes and one without primes. Primed and non-primed conditions ran in parallel. Rooms were isolated from one another and completely private.

On completing the games, participants were led to one of two interview rooms, where research assistants administered the demographic questionnaire. After the questionnaires, participants received and signed for their compensation on their way out. They collected their earnings by dropping their numbered ticket through a louvered window shutter at an enclosed room. Inside, a research assistant received the ticket, collated the earnings in an envelope and passed it the envelope through the louvered shutter.

Participants in the sheltered waiting area had access to refreshments and entertainment in the form of family-friendly films shown on a large screen.

\subsection{Participants}

Table 1 illustrates the basic demographic data for the remaining participants $\left(\mathrm{n}=77, M_{\text {age }}=\right.$ $34.12, S D_{\text {age }}=13.08,40$ females). We organize this by treatment as a check on random assignment. Wilcoxon rank sum tests showed no significant differences between these predictors by condition. Three individuals were deleted from our analyses: according to the data, one individual seems to have added a coin of his/her own to a cup thus rendering the total amount of 
possible coins to be 31 , one coin went missing from one treatment, and one individual seems to have taken a coin from one game and put it into the cup of another game. While we made initial coin counts that were independently re-checked, we cannot know precisely how coins went missing, or were added, in these three instances. Nevertheless, the balance of allocations was offset, and thus the results of the games could not be consistently interpreted in the context of the rest of the sample.

Table 1. Basic demographics per treatment. Note: $M(S D)$ \{number of missing values\}.

\begin{tabular}{|c|c|c|c|c|c|c|c|}
\hline \multirow[t]{2}{*}{ Predictor } & \multirow[t]{2}{*}{ Range/Scale } & \multicolumn{2}{|c|}{ Control } & \multicolumn{2}{|c|}{ Treatment } & \multicolumn{2}{|c|}{ Total } \\
\hline & & $\mathbf{M}(S D)$ & $\begin{array}{c}\text { Missing } \\
\text { Values }\end{array}$ & $\mathbf{M}(S D)$ & $\begin{array}{c}\text { Missing } \\
\text { Values } \\
\end{array}$ & $\mathbf{M}(S D)$ & $\begin{array}{l}\text { Missing } \\
\text { Values }\end{array}$ \\
\hline Age & 17 to 72 & $34.13(13.81)$ & 3 & $34.11(12.47)$ & -- & $34.12(13.08)$ & 3 \\
\hline Formal Ed. in Years & 1 to 17 & $7.89(4.02)$ & 3 & $8.12(2.98)$ & 4 & $8.00(3.53)$ & 7 \\
\hline Children & 0 to 14 & $2.23(2.75)$ & -- & $2.14(2.39)$ & 1 & $2.18(2.56)$ & 1 \\
\hline Material Insecurity & 0 to 1 & $0.91(0.19)$ & -- & $0.81(0.27)$ & -- & $0.86(0.24)$ & -- \\
\hline Material Confidence & 0 to 1 & $0.12(0.76)$ & -- & $0.25(0.92)$ & -- & $0.18(0.84)$ & -- \\
\hline Emotional Closeness to LOCAL & -2 to 2 & $4.14(1.29)$ & 4 & $3.76(1.54)$ & 4 & $3.96(1.42)$ & 8 \\
\hline Emotional Closeness to DISTANT & -2 to 2 & $2.32(1.63)$ & 5 & $2.88(1.63)$ & 5 & $2.60(1.64)$ & 10 \\
\hline Religious Similarity to DISTANT & -2 to 2 & $0.37(1.19)$ & 4 & $0.24(1.30)$ & 9 & $0.31(1.23)$ & 13 \\
\hline Punishment (God) & 0 to 1 & $0.75(0.34)$ & 1 & $0.83(0.30)$ & 3 & $0.79(0.32)$ & 4 \\
\hline Knowledge (God) & 0 to 1 & $0.97(0.16)$ & 1 & $0.97(0.17)$ & 3 & $0.97(0.16)$ & 4 \\
\hline Punishment (Our Lady) & 0 to 1 & $0.63(0.40)$ & 7 & $0.52(0.42)$ & 7 & $0.57(0.41)$ & 14 \\
\hline Knowledge (Our Lady) & 0 to 1 & $0.77(0.42)$ & 7 & $0.83(0.36)$ & 9 & $0.80(0.39)$ & 16 \\
\hline Police Evaluation & -2 to 2 & $-0.14(0.85)$ & 4 & $0.06(1.12)$ & 5 & $-0.04(0.98)$ & 9 \\
\hline Evangelical & -- & 9 & - & 8 & - & 17 & - \\
\hline Catholic & -- & 30 & -- & 30 & -- & 60 & -- \\
\hline n & -- & 39 & -- & 38 & -- & 77 & -- \\
\hline Female & -- & 18 & -- & 22 & -- & 40 & -- \\
\hline
\end{tabular}

Table 2 details the differences between how participants view and relate to God and Our Lady of Nazareth. This indicates that there are major distinctions between these supernatural agents in how they are perceived by participants. God is rated as systematically more punishing, knowledgeable, and concerned with how people treat strangers. Participants think more about God, have higher frequencies of performing rituals devoted to God, and worry about what God thinks of them more often than they do about Our Lady of Nazareth. Supplementary Table S1 is a correlation matrix of our key variables. Note that the key predictors for God-punishment and breadth of knowledge - are significantly correlated $(r=0.28, p \leq 0.05)$.

Table 2. Comparison of Our Lady of Nazareth and God. Note. ${ }^{a}$ Mean difference [confidence intervals]. Significance based on Wilcoxon signed rank tests; ${ }^{b} \mathrm{McNemar}$ 's chi-square test statistic (df); 'One individual preferred not to respond as he/she did not believe in Our Lady and wished to not be disrespectful; ' One "I don't know" was converted into a missing value for God; ${ }^{\mathrm{e}}$ On a 4-point Likert scale (see Purzycki, et al. this volume); ${ }^{* *} p \leq 0.001,{ }^{* *} p \leq 0.01, * p \leq 0.05$; $\dagger p \leq 0.10$

\begin{tabular}{|c|c|c|c|}
\hline Variable & $\begin{array}{c}\text { God } \\
\text { M (SD) }\end{array}$ & $\begin{array}{c}\text { Our Lady } \\
\text { M (SD) }\end{array}$ & Tests of Differences \\
\hline Knowledge Index & $0.97(0.16)$ & $0.80(0.39)$ & $0.17[0.75,1.00]^{* *^{\mathrm{a}}}$ \\
\hline Moralization Index & $2.40(1.09)$ & $2.05(1.13)$ & $0.35[0.17,0.83]^{* * \mathrm{a}}$ \\
\hline Does ___ care about how you treat strangers? & $0.95(0.23)$ & $0.75(0.43)$ & $11.08(1)^{* * * b, c}$ \\
\hline How often do you think about this god? & $3.78(0.73)$ & $2.72(1.63)$ & $1.06[2.00,3.50]^{* * * a}$ \\
\hline
\end{tabular}


... do you perform rituals devoted to this god?

... do you worry about what this god thinks of you?

$3.44(0.88)$

$3.47(1.01)$

$3.81(0.77)^{\mathrm{d}}$
$3.04(1.02)$

$2.53(1.65)$

$2.86(1.55)$
$0.40[0.00,1.50] \dagger$

$0.94[1.00,2.50]^{* * * a}$

$0.95[2.00,3.50]^{* * * a}$

\subsection{Results $^{2}$}

We ran all binomial logistic regressions in $\mathrm{R}$ ( $\mathrm{R}$ Core Team, 2012) using the car package (Fox and Weisberg, 2011) to check for multicollinearity. Pseudo- $R^{2} \mathrm{~s}$ were calculated using the logisticPseudoR2s function in Field, Miles, and Field (2012, p. 334). Age was centered at the mean age (34.12), as was the number of years of formal education $(M=8.00)$. Confidence intervals reported in the multiple regression models are bias and skew-corrected bootstrapped $95 \%$ confidence intervals (1,000 reps). Confidence intervals reported in the mixed effect models were bootstrapped using the percentile method (1,000 reps). We report non-bootstrapped models in the supplementary materials for reference. Odds ratios and confidence intervals $>1$ indicate an increase in the odds of allocating a coin to the DISTANT cup whereas those values $<1$ indicate a decrease in the odds of allocation a coin to the DISTANT cup. We include corrected AIC scores for reference, but acknowledge that models are difficult to compare given the fluctuation in sample sizes due to missing data.

Tables 3 and 4 report five models per game (Local Co-Religionist and Self respectively). Given the current sample size in relation to the size of our set of predictor variables and missing data, the analyses for each game were conducted across five sets of predictor variables: (1) the Null Model, (2) a God Model, (3) an Our Lady Model, (4) a Demographic Model, and (5) a Social Evaluation Model. Null Models include variables for the prime condition (Treatment), whether or not people thought the game was about honesty (Honest), and Game Order. All subsequent models included these variables as well. However, we had to remove HONEST from the bootstrapped multiple regression models as resampling would frequently miss the 5 individuals who mentioned honesty in the post-game interviews. Without any variation in scores on this variable, the model was unable to be estimated. This was not a problem for the stacked games (mixed effect modelling, see below) and so we retained HONEST in these models. God Models included all of the target deity variables for God while Our Lady Models included those for St. Mary. The Demographic Models included only our key demographic variables - material insecurity, material confidence, sex and age of participant, number of children, and years of formal education. Social Evaluation Models include all of the social evaluation questions: police, emotional closeness to DISTANTs and LOCALs, as well as the religious similarity to the DISTANT. We analyzed data across these separate models, as any single model that included all predictor variables would not be statistically powerful given our sample size. This data analytic strategy allowed us to test specific hypotheses regarding the contributions of individual sets of variables to participants' behaviors in the games while maintaining interpretive value of the model's estimates. Further discussion and model specifications can be found in our supplementary materials.

\footnotetext{
${ }^{2}$ For the question that composed the punishment score for God (whether or not God influences what happens to people after they die), we converted a single "I don't know" to a missing value, and replaced one qualitative response ("I think it's 1", “Acho que é 1") with a 1. For emotional proximity to the DISTANT (DISTANTEMO), we converted two "I don't knows" to a missing value and for religious similarity to the DISTANT (DISTANTSIM), we converted six "I don't knows" to missing values.
} 


\subsubsection{Local Co-Religionist Game: DISTANT vs. LOCAL}

In the Local Co-Religionist Game, the average raw allocation to the DISTANT cup was $14.00(S D=3.99)$ for the control condition and $14.87(S D=2.84)$ for the treatment condition. Table 3 presents the models regressing coin allocations for the first game. Across models, although treatment had an effect in the predicted fashion, all lower bounds crossed 1, suggesting we could not rule out the hypothesis of no difference between conditions.

The set of predictors that best explained the allocation of coins according to Nagelkerke's $R^{2}$ were those of the God Model $\left(R^{2}=0.35\right)$. Although the treatment did not have any discernible effects on participant's raw score responses to these questions (see Table 1), we found that the predictive contribution of perceptions of God's knowledge and punishment to coin allocations was slightly moderated by treatment (Interaction $\mathrm{OR}=0.39, \mathrm{CI}=[0.33,0.84], p=.04]$. In unpacking this interaction, we found that the combined God's knowledge and punishment index was significantly positively correlated with allocations to the DISTANT cup in the control condition $(r(36)=0.45, p=.004)$, but not in the treatment condition $(r(33)=0.06, p=.74)$.

We observed a similar pattern of results with our measure of beliefs regarding evaluations of the police (Social Evaluation Model: Interaction OR $=0.75, \mathrm{CI}=[0.57,0.92], p=$ .006 ) and God's rewards (God Model: Interaction $\mathrm{OR}=0.68, \mathrm{CI}=[0.00,0.91], p=.003$ ). In the control condition, positive evaluations of the local police were significantly correlated with allocations to the DISTANT cup $(r(33)=.39, p=.02)$. In the treatment condition, this relationship was not significantly different from zero $(r(31)=-.20, p=.27)$. This pattern of results emerged again in regards to beliefs concerning God's rewards (Control: $r(35)=0.49, p=$ .002 ; Treatment: $r(31)=-.19, p=.29)$.

Taken together, these results point towards the effectiveness of the prime in sustaining more equal allocations (as compared to control) to the two cups when participants hold particular views about God or the police. That is, in the control condition, the extent to which participants believed that, for example, God could know about and punish behaviors predicted more equal distributions. However, in the treatment condition, participants were more likely, regardless of their trait level beliefs, to allocate coins more equally between cups. Figure 1 illustrates the interaction effect when it is included as a variable in the God Model. It shows that the differences between treatment and control conditions are largest when God's knowledge and punishment ratings are low.

[INSERT FIGURE 1 HERE] 
Table 3. Bootstrapped CI models for Local Co-Religionist Game. Note: Variables marked with "G" are "God" variables and "OL" variables refer to "Our Lady". Confidence intervals are bias and skew-corrected based on 1000 bootstrap replicates. ${ }^{\mathrm{a}} \mathrm{Variable}$ centered at mean. $\$ p \leq .15 ; \dagger p \leq .10 ; * p \leq .05 ; * * p \leq .01 ; * * p \leq .001$.

\begin{tabular}{|c|c|c|c|c|c|}
\hline & Null Model & God Model & Our Lady Model & Demographic Model & $\begin{array}{c}\text { Social Evaluation } \\
\text { Model }\end{array}$ \\
\hline & OR [Lower, Upper] & OR [Lower, Upper] & OR [Lower, Upper] & OR [Lower, Upper] & OR [Lower, Upper] \\
\hline Treatment (1 = Treatment) & $1.13[0.93,1.37]^{t}$ & $1.16[0.96,1.47]^{\frac{1}{t}}$ & $1.14[0.92,1.43]$ & $1.22[0.98,1.71]^{*}$ & $1.13[0.90,1.41]$ \\
\hline Knowledge-Punishment (G) & -- & $2.01[0.92,6.86]^{* *}$ & -- & -- & -- \\
\hline Rewards (G) & -- & $1.16[0.94,56.58]^{*}$ & -- & -- & -- \\
\hline Moralism (G) & -- & $0.95[0.83,1.04]$ & -- & -- & -- \\
\hline Knowledge-Punishment (OL) & -- & -- & $1.18[0.72,2.11]$ & -- & -- \\
\hline Rewards (OL) & -- & -- & $0.99[0.91,1.12]$ & -- & -- \\
\hline Moralism (OL) & -- & -- & $0.93[0.74,1.04]^{*}$ & -- & -- \\
\hline Catholic (1 = Catholic) & -- & -- & -- & $0.97[0.75,1.35]$ & -- \\
\hline Mean Material Insecurity & -- & -- & -- & $1.56[0.96,3.54]^{*}$ & -- \\
\hline Mean Material Confidence & -- & -- & -- & $0.94[0.76,1.07]$ & -- \\
\hline Sex $(1=$ Male $)$ & -- & -- & -- & $1.24[0.98,1.67]^{*}$ & -- \\
\hline Age $^{a}$ & -- & -- & -- & $1.01[1.00,1.02]$ & -- \\
\hline Number of Children & -- & -- & -- & $0.99[0.91,1.04]$ & -- \\
\hline Years of Formal Education ${ }^{a}$ & -- & -- & -- & $1.02[1.01,1.06]^{\ddagger}$ & -- \\
\hline Police Evaluation & -- & -- & -- & -- & $1.08[0.99,1.23] \ddagger$ \\
\hline DISTANT Emotional Closeness & -- & -- & -- & -- & $1.06[0.99,1.18] \dagger$ \\
\hline LOCAL Emotional Closeness & -- & -- & -- & -- & $0.96[0.85,1.06]$ \\
\hline DISTANT Rel. Similarity & -- & -- & -- & -- & $1.00[0.90,1.14]$ \\
\hline Order $(1=$ Loc. Com. Game First $)$ & $1.08[0.86,1.31]$ & $1.15[0.96,1.43] \dagger$ & $1.11[0.81,1.40]$ & $1.07[0.84,1.36]$ & $1.02[0.68,1.38]$ \\
\hline Constant & $0.84[0.68,1.01]^{*}$ & $0.28[0.00,1.14]^{* * *}$ & $0.89[0.58,1.31]$ & $0.51[0.22,0.85]^{* *}$ & $0.89[0.54,1.32]$ \\
\hline$N$ & 77 & 68 & 56 & 69 & 61 \\
\hline AICc & 430.61 & 376.17 & 325.99 & 399.01 & 343.12 \\
\hline Nagelkerke's $R^{2}$ & 0.04 & 0.35 & 0.12 & 0.25 & 0.18 \\
\hline Mean VIF & 1.01 & 1.05 & 1.46 & 1.32 & 1.30 \\
\hline
\end{tabular}


Figure 1. The interaction of treatment and God's knowledge-punishment in predicting allocations to the DISTANT in the Local Co-Religionist Game.

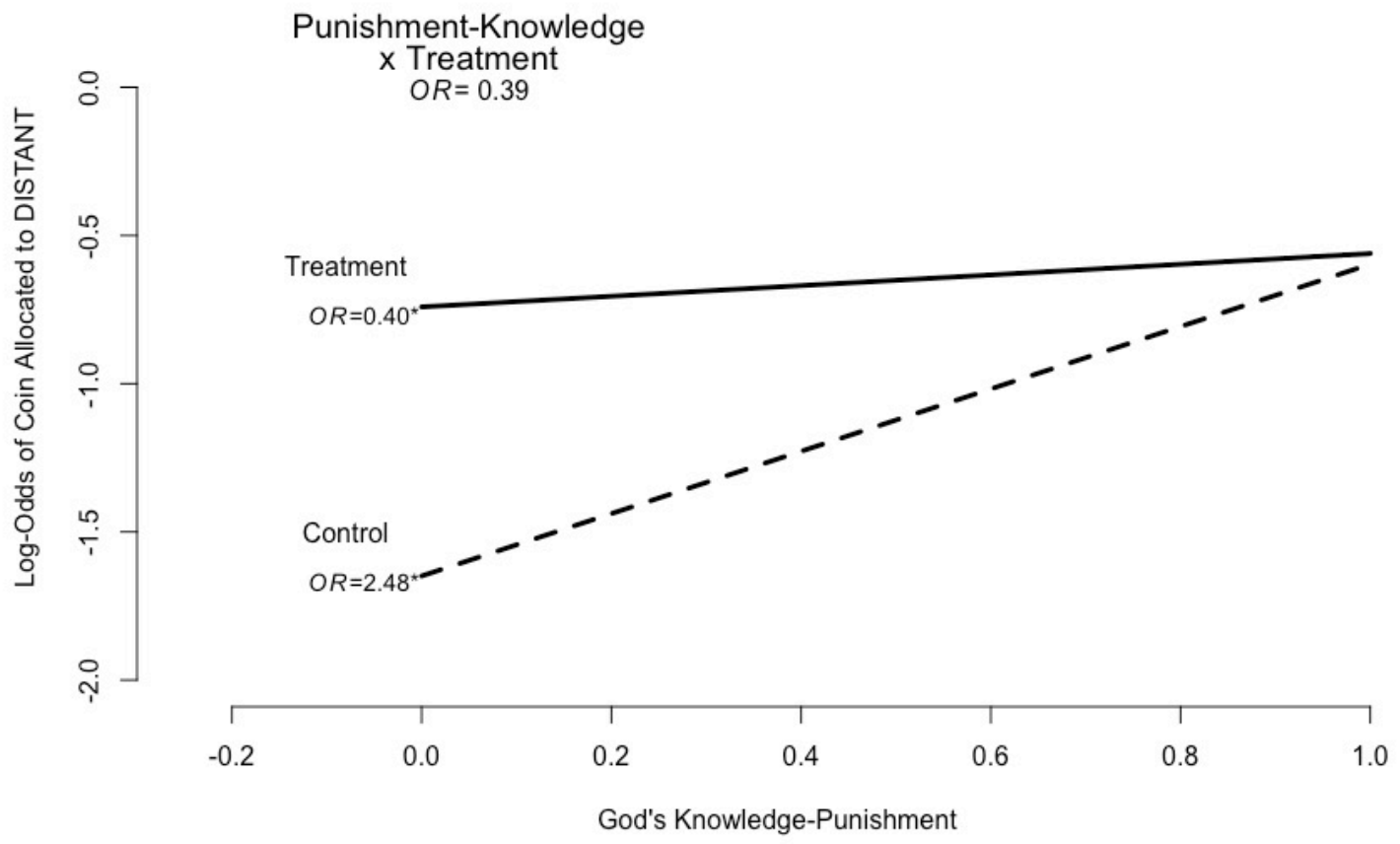

\subsubsection{Self Game: DISTANT vs. SELF}

Table 4 presents the models regressing coin allocations for the Self Game. As in the first game, across models the treatment effect trended in the predicted fashion, but this effect was only reliable (i.e., did not cross 1) in the Social Evaluation Models. The average raw allocation to the DISTANT (Christian from Rondon) cup for the control condition was $14.13(S D=4.27)$ while the treatment condition was $15.03(S D=3.10)$. Beliefs regarding Our Lady of Nazareth's punishment trended towards increasing the odds that a coin went into the DISTANT cup (OR $=$ $1.44, \mathrm{CI}=[0.98,2.79], p=.06$; see note 4$)$.

In this game, the Demographic $\left(R^{2}=0.46\right)$ and God models $\left(R^{2}=0.45\right)$ accounted for the most variance in allocation. As in the Local Co-Religionist Game, following these analyses we then explored possible interactions of the variables with treatment. There was an interaction between treatment and God's knowledge and punishment in predicting coin allocations (God Model: $\mathrm{OR}=0.79, \mathrm{CI}=[0.16,3.20], p=.63)$. The same pattern of results seen in the Local CoReligionist Game emerges when examining the correlation between God's knowledge and punishment and allocations (Control: $r(36)=.31, p=.05$; Treatment: $r(33)=.22, p=.21$ ). God's rewards (God Model: $\mathrm{OR}=0.84, \mathrm{CI}=[0.00,1.06], p=.15)$, and evaluations of the police (Social Evaluation Model: $\mathrm{OR}=0.78, \mathrm{CI}=[0.60,1.11], p=.02$ ) similarly had an interaction effect with condition on allocations. Again, beliefs about God's rewarding of proper behaviors significantly correlated with allocations to the DISTANT cup only in the control condition $(r(35)$ $=.35, p=.03)$ and not in the treatment condition $(\mathrm{r}(31)=.15, p=.39)$. This was the case also for 
evaluations of the police (Control: $r(33)=.49, p=.003$; Treatment: $r(31)=-0.03, p=.83$ ). As such, similar to the Local Co-Religionist Game, the prime sustained more equal allocations to the two cups, regardless of participants' trait level beliefs even when cheating would be more directly beneficial to the self. 
Table 4. Bootstrapped CI models for Self Game. Note: Variables marked with "G" are "God" variables and "OL" variables refer to

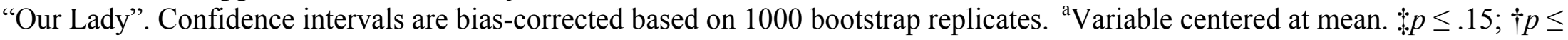
$.10 ; * p \leq .05 ; * * p \leq .01 ; * * * p \leq .001$.

\begin{tabular}{|c|c|c|c|c|c|}
\hline & Null Model & God Model & Our Lady Model & Demographic Model & $\begin{array}{c}\text { Social Evaluation } \\
\text { Model }\end{array}$ \\
\hline & OR [Lower, Upper] & OR [Lower, Upper] & OR [Lower, Upper] & OR [Lower, Upper] & OR [Lower, Upper] \\
\hline Treatment $(1=$ Treatment $)$ & $1.10[0.89,1.39]$ & $1.10[0.92,1.40]$ & $1.24[0.98,1.65]^{*}$ & $1.09[0.87,1.47]$ & $1.24[1.02,1.59]^{*}$ \\
\hline Knowledge-Punishment (G) & -- & $1.86[0.95,5.05]^{* *}$ & - - & -- & -- \\
\hline Rewards (G) & -- & $1.18[1.04,512.66]^{* *}$ & -- & -- & -- \\
\hline Moralism (G) & -- & $1.07[0.97,1.23] \dagger$ & -- & -- & -- \\
\hline Knowledge-Punishment (OL) & -- & -- & $1.44[0.98,2.79] \dagger$ & -- & -- \\
\hline Rewards (OL) & -- & -- & $0.98[0.89,1.07]$ & -- & -- \\
\hline Moralism (OL) & -- & -- & $1.01[0.83,1.12]$ & -- & -- \\
\hline Catholic $(1=$ Catholic $)$ & -- & -- & -- & $0.70[0.49,0.87]^{* *}$ & -- \\
\hline Mean Material Insecurity & -- & -- & -- & $0.96[0.46,1.91]$ & -- \\
\hline Mean Material Confidence & -- & -- & -- & $0.94[0.75,1.09]$ & -- \\
\hline Sex $(1=$ Male $)$ & -- & -- & -- & $0.89[0.66,1.14]$ & -- \\
\hline $\operatorname{Age}^{a}$ & -- & -- & -- & $1.00[1.00,1.02]$ & -- \\
\hline Number of Children & -- & -- & -- & $0.95[0.86,1.00]^{*}$ & -- \\
\hline Years of Formal Education ${ }^{a}$ & -- & -- & -- & $0.99[0.94,1.01]$ & -- \\
\hline Police Evaluation & -- & -- & -- & -- & $1.17[1.03,1.40]^{* *}$ \\
\hline DISTANT Emotional Closeness & -- & -- & -- & -- & $1.01[0.95,1.11]$ \\
\hline LOCAL Emotional Closeness & -- & -- & -- & -- & $1.01[0.87,1.14]$ \\
\hline DISTANT Rel. Similarity & -- & -- & -- & -- & $1.03[0.91,1.16]$ \\
\hline Order $(1=$ Loc. Com. Game First $)$ & $0.75[0.61,0.94]^{* * *}$ & $0.75[0.59,0.92]^{* *}$ & $0.78[0.59,0.98]^{*}$ & $0.77[0.60,0.93]^{* *}$ & $0.81[0.53,1.06] \dagger$ \\
\hline Constant & $1.04[0.88,1.26]$ & $0.28[0.00,0.86]^{* * *}$ & $0.76[0.48,1.11] \dagger$ & $1.66[0.96,4.53]^{*}$ & $0.93[0.56,1.58]$ \\
\hline$N$ & 77 & 69 & 57 & 68 & 61 \\
\hline AICc & 440.87 & 386.64 & 326.63 & 402.22 & 351.62 \\
\hline Nagelkerke's $\boldsymbol{R}^{2}$ & 0.18 & 0.45 & 0.32 & 0.46 & 0.35 \\
\hline Mean VIF & 1.01 & 1.04 & 1.45 & 1.31 & 1.30 \\
\hline
\end{tabular}




\subsubsection{Mixed Effects Models for Both Games}

In order to evaluate and account for any potential differences in how individual participants played the two games, we further analyzed the data of both games simultaneously by using mixed effect modelling with participants as a random effect (McNamara, Norenzayan, and Henrich, 2016; Purzycki, et al., 2016). This procedure entails stacking the two data sets on top of each other and reproducing the predictors for each set. DISTANT cup allocations were placed into one column, and the SELF and LOCAL cups placed into another. We created a dummy variable $(1=$ Local Co-Religionist Game $)$ in order to determine whether or not players differentially biased allocations across games. In models using pooled games, we used participants as random effects and all other factors as fixed effects. As above, we analyzed data across five models (Null, God, Our Lady, Demographic, and Social Evaluation Models).

These models are presented in Table 5. Across models, the p-values of Treatment hovered above traditional levels of significance, but the effect was stable across models in terms of the direction of the odds ratio and confidence intervals. We could not rule out the hypothesis of no effect of game in any of these models; participant allocations between cups did not obviously differ between the Local Co-Religionist Game and the Self Game. In other words, participants were not any more likely to favor themselves over their local community. As in the analyses of the individual games, beliefs in God's knowledge and punishment $(\mathrm{OR}=2.17, \mathrm{CI}=$ $[1.43,3.37], p<.001)$ most strongly predicted increased allocations to the distant co-religionist's cup. In the Our Lady Model, Our Lady's knowledge and punishment was consistent with the hypothesis of no effect on allocations. 
Table 5. Mixed Effects Models for Stacked Games with Bootstrapped CIs. Note: Participants included as random effects. Variables marked with "G" are "God" variables and "OL" variables refer to "Our Lady". Confidence intervals are percentile bootstrapped based on 1000 replicates. ${ }^{a}$ Variable centered at mean. ${ }^{b}$ Dropped as including this variable in tandem with any other God variable prevented the model from converging. $\$ p \leq .15 ; \dagger p \leq .10 ; * p \leq .05 ; * * p \leq .01 ; * * * p \leq .001$.

\begin{tabular}{|c|c|c|c|c|c|}
\hline & Null Model & God Model & Our Lady Model & Demographic Model & $\begin{array}{c}\text { Social Evaluation } \\
\text { Model }\end{array}$ \\
\hline & OR [Lower, Upper] & OR [Lower, Upper] & OR [Lower, Upper] & OR [Lower, Upper] & OR [Lower, Upper] \\
\hline Treatment $(1=$ Treatment $)$ & $1.12[0.94,1.32]$ & $1.14[0.97,1.36]^{\dagger}$ & $1.19[0.97,1.46]^{\dagger}$ & $1.15[0.97,1.39]^{\dagger}$ & $1.19[0.97,1.45]^{+}$ \\
\hline Knowledge-Punishment (G) & -- & $2.17[1.43,3.37]^{* * *}$ & -- & -- & -- \\
\hline Rewards (G) & -- & b & -- & -- & -- \\
\hline Moralism (G) & -- & $1.00[0.92,1.08]$ & -- & -- & -- \\
\hline Knowledge-Punishment (OL) & -- & -- & $1.32[0.87,2.01]$ & -- & -- \\
\hline $\operatorname{Rewards}(\mathrm{OL})$ & -- & -- & $0.98[0.89,1.08]$ & -- & -- \\
\hline Moralism (OL) & -- & -- & $0.96[0.86,1.07]$ & -- & -- \\
\hline Catholic (1 = Catholic) & -- & -- & -- & $0.83[0.66,1.01]^{\dagger}$ & -- \\
\hline Mean Material Insecurity & -- & -- & -- & $1.20[0.87,1.79]$ & -- \\
\hline Mean Material Confidence & -- & -- & -- & $0.94[0.83,1.04]$ & -- \\
\hline Sex $(1=$ Male $)$ & -- & -- & -- & $1.03[0.88,1.30]$ & -- \\
\hline $\operatorname{Age}^{a}$ & -- & -- & -- & $1.00[1.00,1.01]$ & -- \\
\hline Number of Children & -- & -- & -- & $0.98[0.93,1.02]$ & -- \\
\hline Years of Formal Education ${ }^{a}$ & -- & -- & -- & $1.00[0.98,1.04]$ & -- \\
\hline Police Evaluation & -- & -- & -- & - & $1.13[1.03,1.25]^{*}$ \\
\hline DISTANT Emotional Closeness & -- & -- & -- & -- & $1.04[0.97,1.11]$ \\
\hline LOCAL Emotional Closeness & -- & -- & -- & -- & $0.98[0.90,1.07]$ \\
\hline DISTANT Rel. Similarity & -- & -- & -- & -- & $1.02[0.94,1.11]$ \\
\hline Honest $(1$ = Honesty Mentioned $)$ & $1.01[0.71,1.44]$ & $0.98[0.71,1.36]$ & $0.85[0.45,1.48]$ & $0.97[0.69,1.36]$ & $0.98[0.67,1.41]$ \\
\hline Order $(1=$ Loc. Com. Game First $)$ & $0.89[0.75,1.06]$ & $0.90[0.76,1.06]$ & $0.92[0.75,1.13]$ & $0.91[0.74,1.09]$ & $0.90[0.71,1.14]$ \\
\hline Game (1 = Loc. Com. Game $)$ & $0.98[0.88,1.09]$ & $0.97[0.85,1.09]$ & $1.03[0.90,1.18]$ & $0.98[0.87,1.11]$ & $0.94[0.82,1.08]$ \\
\hline Constant & $0.94[0.80,1.12]$ & $0.49[0.32,0.69]^{* * *}$ & $0.82[0.58,1.18]$ & $0.94[0.63,1.35]$ & $0.94[0.66,1.39]$ \\
\hline$N$ & 77 & 70 & 57 & 69 & 61 \\
\hline AICc & 858.50 & 776.87 & 632.67 & 794.25 & 674.92 \\
\hline Mean VIF & 1.02 & 1.04 & 1.34 & 1.27 & 1.26 \\
\hline
\end{tabular}


Table 6 includes a full, null, and God model where the latter two include only those individuals from the Full Model. Note again, however, that due to the low sample size, the results from the Full Model are to be interpreted with caution, but we again bootstrapped the confidence intervals. The corrected AIC score for the God model is lowest and therefore the better fit. In this case, Treatment $(\mathrm{OR}=1.31, \mathrm{CI}=[1.15,1.88], p=.02)$ and God's rewards $(\mathrm{OR}=1.35,95 \% \mathrm{CI}=$ $[1.33,1.88], p<0.001)$ appear to have stable effects on allocating coins to the distant coreligionist. In the Full Model, features of Our Lady of Nazareth beliefs also appear to play a positive role in the chances of allocating a coin to a Christian from Rondon. However, given that these variables are correlated with their counterparts for God (see supplements), removing these also improves variance inflation that results from multicollinearity as indicated by the drop in mean variance inflation factor. Consistent with the single game results, God's KnowledgePunishment has an overall effect on the chances that a coin goes to the distant co-religionist. Curiously, material insecurity and confidence show strong effects even though their contributions to explaining allocations differed across single games. In this case, material insecurity predicted greater odds of putting a coin into the DISTANT cup, while material confidence predicted the reverse. These results are discussed below.

Table 6. Compared Null and Full Mixed Effects Models for Stacked Games with Bootstrapped CIs. Note: Participants included as random effects. Confidence intervals are percentile bootstrapped based on 1000 replicates. Variables marked with "G" are "God" variables and "OL" variables refer to "Our Lady". "Variable centered at its mean. $\$ p \leq .15 ; \uparrow p \leq .10 ; * p \leq$ $.05 ; * * p \leq .01 ; * * * p \leq .001$.

\begin{tabular}{|c|c|c|c|}
\hline & Null Model & Full Model & God Model \\
\hline & OR [Lower, Upper] & OR [Lower, Upper] & OR [Lower, Upper] \\
\hline Treatment $(1=$ Treatment $)$ & -- & $1.47[1.15,1.88]^{* *}$ & $1.31[1.07,1.58]^{*}$ \\
\hline Knowledge-Punishment (G) & -- & $2.03[1.17,3.51]^{*}$ & $2.46[1.67,3.61]^{* * *}$ \\
\hline Rewards (G) & -- & $1.58[1.33,1.88]^{* * *}$ & $1.35[1.21,1.52]^{* * *}$ \\
\hline Moralism (G) & -- & $1.11[0.97,1.27]$ & $1.14[1.02,1.26]^{*}$ \\
\hline Knowledge-Punishment (OL) & -- & $1.90[1.12,3.22]^{*}$ & -- \\
\hline Rewards (OL) & -- & $0.89[0.80,0.99]^{*}$ & -- \\
\hline Moralism (OL) & -- & $1.07[0.94,1.22]$ & -- \\
\hline Catholic (1 = Catholic) & -- & $0.71[0.48,1.06]^{\dagger}$ & $0.94[0.74,1.23]$ \\
\hline Mean Material Insecurity & -- & $2.21[1.42,3.46]^{* * *}$ & $2.03[1.45,2.93]^{* * *}$ \\
\hline Mean Material Confidence & -- & $0.80[0.70,0.91]^{* *}$ & $0.75[0.66,0.86]^{* * *}$ \\
\hline Sex (1= Male $)$ & -- & $1.07[0.84,1.38]$ & $1.27[1.03,1.56]^{*}$ \\
\hline $\operatorname{Age}^{\mathrm{a}}$ & -- & $1.00[0.99,1.01]$ & $1.00[0.99,1.01]$ \\
\hline Number of Children & -- & $0.94[0.89,0.98]^{* *}$ & $0.95[0.91,1.00]^{*}$ \\
\hline Years of Formal Education ${ }^{a}$ & -- & $0.99[0.95,1.03]$ & $1.00[0.95,1.04]$ \\
\hline Police Evaluation & -- & $1.11[0.98,1.27]^{\ddagger}$ & $1.21[1.09,1.37]^{* *}$ \\
\hline DISTANT Emotional Closeness & -- & $1.03[0.95,1.12]$ & $1.03[0.95,1.12]$ \\
\hline LOCAL Emotional Closeness & -- & $0.99[0.91,1.08]$ & $1.02[0.95,1.12]$ \\
\hline DISTANT Rel. Similarity & -- & $0.97[0.87,1.09]$ & $1.01[0.89,1.13]$ \\
\hline Honest $(1=$ Honesty Mentioned $)$ & -- & $0.67[0.35,1.26]$ & $0.80[0.55,1.24]$ \\
\hline Order $(1=$ Loc. Com. Game First $)$ & -- & $0.95[0.72,1.27]$ & $0.91[0.73,1.15]$ \\
\hline Game $(1=$ Loc. Com. Game $)$ & -- & $0.96[0.82,1.12]$ & $0.96[0.82,1.11]$ \\
\hline Constant & $0.91[0.79,1.05]$ & $0.03[0.01,0.09]^{* * *}$ & $0.04[0.02,0.07]^{* * *}$ \\
\hline$N$ & 42 & 42 & 42 \\
\hline AICc & 479.03 & 470.39 & 469.93 \\
\hline Mean VIF & -- & 2.48 & 1.88 \\
\hline
\end{tabular}




\section{Discussion}

In this study, the primes had an effect on gameplay; when participants played the games near the Bible and cross pendant, they allocated more to distant co-religionists in Rondon - although with some variability. Note in Figs. S1 and S2 that modal allocations to the Self (Mode = 17) and Local Co-Religionist (Mode $=16$ ) were more frequent than expected by the binomial distribution. This may be interpreted as players consciously giving themselves and their local communities more coins, but with self-imposed constraints. In other words, while this sample was willing to cheat, they systematically did so but not excessively.

We must note again that the low sample size tempers our confidence in these results. As the effect of the treatment condition varied considerably across within-game models, only larger samples will facilitate more reliable assessments of the prime's effects for specific dyadic allocations, particularly with the inclusion of other predictor variables of theoretical importance. In the pooled game models (Table 6), however, the treatment condition clearly had an effect, as did the other core religiosity variables. In other words, when holding other variables constant, the treatment did actually appear to increase allocations to remote co-religionists across games.

Interestingly, and speaking to the effectiveness of the prime in sustaining more equitable allocations to the two cups, our measures of trait-level beliefs were only obviously related to allocations in the control conditions in either of the games. This provides converging evidence for our primary hypothesis. In the absence of any prime, ratings of God's knowledge and punishment correlate with allocations to a distant co-religionist. Thus, unlike in more typical North American samples in which trait-level religious beliefs do not predict prosocial behaviors (Norenzayan \& Shariff, 2007), here we find evidence that trait-level beliefs do play an important role in predicting prosocial allocations of coins to an unknown co-religionist. However, when participants played these games in front of religious symbols, their trait level beliefs were no longer associated with coin allocations, even though participants gave, on average, more coins to the distant co-religionist. Importantly, there were no detectable differences in trait level beliefs between conditions, suggesting that, in the treatment condition, the religious prime was the primary motivator for increased allocations to the distant co-religionist in this study.

Previous work has demonstrated that supernatural punishment beliefs reduce cheating, whereas supernatural benevolence beliefs (that extent to which God is loving and kind) actually increase cheating (Shariff and Norenzayan 2011). In the present study, although we did not directly assess participants' perceptions of God as a loving and forgiving agent, the measure of the extent to which God rewards good behaviors may serve as an interesting proxy. However, here we find the reverse effect. That is, claims regarding God as more rewarding predicted prosociality rather than selfishness. Note again, however, there was a ceiling effect for this question. It may be that this behavior is due in part to the prevalent "prosperity-theology" belief across Brazil that tithes, offerings, and sacrificial giving to the church, even or especially in times of financial hardship, will be looked on favorably by God and will eventually be rewarded. Future work may consider this as a point of comparison as an important factor to measure.

Additionally, and contrary to other work (Hruschka, et al. 2014; McNamara, Norenzayan, \& Henrich, 2016), average material security predicted an increase in allocations to the DISTANT's cup in the Local Co-Religionist Game. In this context, material insecurity predicted reduced parochial favoritism. Beyond the possible influence of the aforementioned "prosperity- 
theology", there are no obvious site-specific interpretations for this pattern. In light of the contrary results from other work and from our stacked games analysis, we again treat these results with caution. One interpretation, however, could be that those who were more materially secure retained more coins not because of need or worry, but rather because of relatively greater dispositional care or frugality in their handling of money, though it is unclear why the same pattern of results would not occur in the Self Game. Another interpretation is that less materially secure individuals are more inclined to favor those beyond their existing networks due to factors associated with perceived opportunities for beneficial reciprocity. This interpretation assumes some kind of latent exchange psychology is activated even in our anonymous one-off game context and that relatively more materially insecure participants are more likely than materially secure participants to be sensitive to (low-cost) opportunities to expand the cooperative networks on which they depend (see Piff et al., 2010). Alternatively, materially insecure participants may have given more due to attitudes toward distant co-religionists that are otherwise unaccounted for in our intergroup questions (e.g., perhaps distant co-religionists are perceived to need more). Future ethnographic and experimental research could investigate further the conditions in which material insecurity and other factors reliably associated with it can mitigate biases toward one's own group.

Compared with the other groups in the present volume, this sample was the only one with an effect of the prime in the predicted direction (see McNamara \& Henrich; Purzycki \& Kulundary; Willard; Xygalatas, et al., this volume). This slight effect held even when accounting for any potential differences in the two games, their targets and how participants approached playing them. This can be interpreted in a variety of ways. First, this sample is the only sample with the historically deepest association with Christianity and it is consistent with the bulk of extant religious priming studies relies on Christian, North American samples. It remains difficult to say exactly how the prime functions. Despite the fact that the effect of primes crossed the boundary of no effect on ratings of God's punishment, knowledge, or reward, the prime did seem to override the contributing effects of these variables in predicting prosociality. It may be that, psychologically, the association between Christian symbols, such as the Bible and the cross, and cooperation are so regularized among Christians that the priming of psychological systems responsible for fairness and cooperation and their mental associations with Christian symbolism is automatic. This implicit effect may be even stronger where religious symbolism is pervasive in homes and public spaces and there are few dominant alternative religious models, as is the case in Pesqueiro. Throughout Latin America, public religious symbols are ubiquitous. Given that the present sample does not rank among the fairer-playing of the samples included in this crosscultural programme of research, further comparative investigation is required to examine whether or not public religious symbols have an effect on sociality more generally.

Notably, Our Lady of Nazareth functioned similarly to a High God only in the Our Lady Models; when not considering the effects of God, St. Mary appears to predict increased odds of allocating coins to distant co-religionists and this effect was especially strong in the Self Game. As Our Lady has local significance and has clear, close conceptual links to the Christian God, this may translate into co-opting the often-reported functions of moralistic, punitive, and allknowing deities. As Mary is so closely related to God in the Catholic worldview, this may explain this effect.

In summary, with important caveats around sample size this study found that symbolic religious cues and beliefs about God and Our Lady of Nazareth, as knowledgeable, punishing agents who are intimately engaged in people's everyday lives at personal and community levels, 
influence people's private decisions about resource allocation in an economic game. In regards to participants' beliefs about God's propensity to reward good behavior and widely-supported hypotheses regarding material insecurity, behaviors in these games were not consistently in the predicted direction and diverged from patterns identified in other groups in our cross-cultural sample. Follow-up systematic research into conceptualizations of not just God and St. Mary, but also participants' views concerning their position and identity in relation to the local and religious groups that were the targets of their decisions, could helpfully inform our interpretations of these variations. Taken together, these data provide some support for the efficacy of both religious priming and conceptions of punishing and rewarding supernatural agents in fostering prosociality in Brazil.

\section{References}

Alves, I. (2005). A festiva devoção no Círio de Nossa Senhora de Nazaré [Festive devotion in the Círio of Our Lady of Nazareth]. Estudos Avançados, 19(54), 315-332.

Alves Filho, A., de Souza Júnior, J. A., \& Neto, J. M. B. (2001). Pontos de história da Amazônia (Vol. 1) [Points of history of Amazonia]. Belém, PA, Brazil: Editora Paka-Tatu.

Barbosa, M.J.S., Eid, F., Santos, M.A.R., Carvalho, K.F., Guedes, L.P.F., Santos, R.A.S., Cruz, W.C., Souza, E.J.L., \& Felix, O.D.L. (2012). Relatório Analítico do Território do Marajó [Analytical Report of the Territory of Marajó]. URL: http://sit.mda.gov.br/download/ra/ra129.pdf

Bering, J. M., McLeod, K., \& Shackelford, T. K. (2005). Reasoning about dead agents reveals possible adaptive trends. Human Nature, 16(4), 360-381.

Brondízio, E. S. (2008). The Amazonian Caboclo and the Açaí Palm: Forest Farmers in the Global Market. New York: New York Botanical Garden Press.

Burnham, K. P., Anderson, D. R., \& Huyvaert, K. P. (2011). AIC model selection and multimodel inference in behavioral ecology: some background, observations, and comparisons. Behavioral Ecology and Sociobiology, 65(1), 23-35.

Cohen, E. (2007). The Mind Possessed: The Cognition of Spirit Possession in an Afro-Brazilian Religious Tradition. New York: Oxford University Press.

Coutinho, R. Z., \& Golgher, A. B. (2014). The changing landscape of religious affiliation in Brazil between 1980 and 2010: age, period, and cohort perspectives. Revista Brasileira de Estudos de População, 31(1), 73-98.

da Cruz, M. E (1987). Marajó, essa imensidão de ilha [Marajó, this immense island]. São Paulo: No Publisher.

de Castilho, E. A., \& Kalil, J. (2005). Ética e pesquisa médica: princípios, diretrizes e regulamentações. Rev Soc Bras Med Trop, 38 (4), 344-347;

Fehr, E., \& Leibbrandt, A. (2011). A field study on cooperativeness and impatience in the Tragedy of the Commons. Journal of Public Economics, 95(9-10), 1144-1155.

Field, A., Miles, J., \& Field, Z. (2012). Discovering Statistics Using R. Thousand Oaks: SAGE Publications Ltd.

Fox, J, and S. Weisberg (2011). An $\{\mathrm{R}\}$ Companion to applied regression. Thousand Oaks, CA: Sage. URL: http://socserv.socsci.mcmaster.ca/jfox/Books/Companion

Galen, L. W. (2012). Does religious belief promote prosociality? A critical examination. Psychological bulletin, 138(5), 876-906. 
Haley, K. J., \& Fessler, D. M. T. (2005). Nobody's watching?: Subtle cues affect generosity in an anonymous economic game. Evolution and Human Behavior, 26(3), 245-256.

Heckenberger, M. J., Christian Russell, J., Toney, J. R., \& Schmidt, M. J. (2007). The legacy of cultural landscapes in the Brazilian Amazon: implications for biodiversity. Philosophical Transactions of the Royal Society B: Biological Sciences, 362(1478), 197-208.

Henrich, J., Heine, S. J., \& Norenzayan, A. (2010). The weirdest people in the world? Behavioral and Brain Sciences, 33(2-3), 61-83.

Hruschka, D., Efferson, C., Jiang, T., Falletta-Cowden, A., Sigurdsson, S., McNamara, R., ... Henrich, J. (2014). Impartial institutions, pathogen stress and the expanding social network. Human Nature, 25(4), 567-579.

IBGE, 2010. Census of the Brazilian Institute for Geography and Statistics. URL: www.ibge.gov.br

Isbell, W. (Eds.), Handbook of South American Archaeology, 339-357. New York: Springer.

Jiang, T. (2013). Cheating in mind games: The subtlety of rules matters. Journal of Economic Behavior \& Organization, 93, 328-336.

Johnson, D. D. P. (2015). God Is Watching You: How the Fear of God Makes Us Human. New York: Oxford University Press.

Johnson, P.C. (2002). Secrets, Gossip, and the Gods: The Transformation of Brazilian Candomblé. New York: Oxford University Press.

Mathew, S., \& Boyd, R. (2011). Punishment sustains large-scale cooperation in prestate warfare. Proceedings of the National Academy of Sciences, 108(28), 11375-11380.

McKay, R., Efferson, C., Whitehouse, H., \& Fehr, E. (2011). Wrath of God: religious primes and punishment. Proceedings of the Royal Society of London B: Biological Sciences, 278(1713), 1858-1863.

McNamara, R. A., Norenzayan, A. \& Henrich, J. (2016). Supernatural punishment, in-group biases, and material insecurity: Experiments and ethnography from Yasawa, Fiji. Religion, Brain \& Behavior, 6(1), 34-55.

Mundry, R., \& Nunn, C. L. (2009). Stepwise model fitting and statistical inference: turning noise into signal pollution. The American naturalist, 173(1), 119-123.

Nappo, S. A., Iafrate, G. B., \& Sanchez, Z. M. (2013). Motives for participating in a clinical research trial: a pilot study in Brazil. BMC Public Health, 13(19), 1-9

Nettle, D., Harper, Z., Kidson, A., Stone, R., Penton-Voak, I. S., \& Bateson, M. (2013). The watching eyes effect in the Dictator Game: it's not how much you give, it's being seen to give something. Evolution and Human Behavior, 34(1), 35-40.

Pantoja, V., \& Maués, R. H. (2012). O Círio de Nazaré na constituição e expressão de uma identidade regional amazônica [The Círio de Nazaré in the constitution and expression of a regional Amazonian identity]. Espaço e Cultura, (24), 57-68.

Piazza, J., Bering, J. M., \& Ingram, G. (2011). "Princess Alice is watching you”: Children's belief in an invisible person inhibits cheating. Journal of Experimental Child Psychology, 109(3), 311-320.

Piff, P. K., Kraus, M. W., Côté, S., \& Cheng, B. H. (2010). Having less, giving more: the influence of social class on prosocial behavior. Journal of Personality and Social Psychology, 99(5): 771-784.

Pichon, I., Boccato, G., \& Saroglou, V. (2007). Nonconscious influences of religion on prosociality: a priming study. European Journal of Social Psychology, 37(5), 1032-1045. 
Purzycki, B. G., Norenzayan, A., Apicella, C., Atkinson, Q. D., Cohen, E., McNamara, R. A., ... Henrich, J. (2016). Moralizing gods, supernatural punishment, and the expansion of human sociality. Nature, 530(7590): 327-330

R Core Team (2012). R: A language and environment for statistical computing. R Foundation for Statistical Computing, Vienna, Austria. ISBN 3-900051-07-0, URL: http://www.Rproject.org/.

Randolph-Seng, B., \& Nielsen, M. E. (2007). Honesty: One effect of primed religious representations. International Journal for the Psychology of Religion, 17(4), 303-315.

Ribeiro, D. (2000). The Brazilian People: The Formation and Meaning of Brazil. Gainesville: University Press of Florida.

Schaan, D. (2008). The Nonagricultural Chiefdoms of Marajó Island. In: Silverman, H., The Handbook of South American Archaeology, 339-357.

Sears, D. O. (1986). College sophomores in the laboratory: Influences of a narrow data base on social psychology's view of human nature. Journal of Personality and Social Psychology, 51(3), 515-530.

Shariff, A. F., \& Norenzayan, A. (2007). God is watching you: priming God concepts increases prosocial behavior in an anonymous economic game. Psychological Science, 18(9), 803-

Shariff, A. F., \& Norenzayan, A. (2011). Mean Gods Make Good People: Different Views of God Predict Cheating Behavior. International Journal for the Psychology of Religion, 21(2), 85-96.

Shariff, A. F., Willard, A. K., Andersen, T., \& A. Norenzayan. (in press). Religious priming: A meta-analysis with a focus on prosociality. Personality and Social Psychology Review.

Whittingham, M. J., Stephens, P. A., Bradbury, R. B., \& Freckleton, R. P. (2006). Why do we still use stepwise modelling in ecology and behaviour? Journal of animal ecology, 75(5), 1182-1189. 